\title{
4-HYDROXYPYRAZOLO (3,4-d) PYRIMIDINE (HPP) IN THE TREATMENT OF GOUT PRELIMINARY OBSERVATIONS
}

BY

\author{
A. P. HALL, V. P. HOLLOWAY, AND J. T. SCOTT \\ Department of Medicine, Postgraduate Medical School, London
}

4-hydroxypyrazolo (3,4-d) pyrimidine (B.W. 56-158: HPP) is a potent inhibitor of the enzyme xanthine oxidase. It was first used in the treatment of leukaemia to suppress the oxidation of 6-mercaptopurine to the therapeutically inert metabolite 6-thiouric acid, and the observation that it lowered the concentration of uric acid in serum and urine has led to its use in gout (Rundles, Wyngaarden, Hitchings, Elion, and Silberman, 1963; Klinenberg, Goldfinger, Miller, and Seegmiller, 1963). Fig. 1 shows the chemical structure of HPP; it is an isomer of hypoxanthine and it inhibits the oxidation of the oxypurines hypoxanthine and xanthine to uric acid. The oxypurines are more soluble than uric acid and are excreted in the urine.<smiles>CC1NCNC2NCCCC12</smiles><smiles>NC1NCNC2NC(=O)C12</smiles>

4-HYOROXYPYRAZOLO (3,4-d) PYRIMIDINE (H.P.P.)<smiles>O=C1NC2C(=O)N[C@@H](O)N[C@H]2N1</smiles>

(a)

Fig. 1. (a).-Structure of hypoxanthine, HPP, and uric acid.

\section{Material and Methods}

This paper describes our preliminary experience with HPP in four patients with gout. They were in-patients for the first few weeks of treatment and took a low purine diet during this period.

Serum and urinary uric acids were estimated by Folin's method (Folin and Dennis, 1912-1913) modified for use on the Technicon Autoanalyser; urinary oxypurines were estimated by differential spectrophotometry (Rundles and others, 1963). The method of serum uric acid estimation has been previously standardized using sera from the population survey of Popert and Hewitt (1962). The upper limit of normal for males and post-menopausal women is $6 \mathrm{mg}$. $/ 100 \mathrm{ml}$. and for pre-menopausal women $5 \mathrm{mg} . / 100 \mathrm{ml}$.

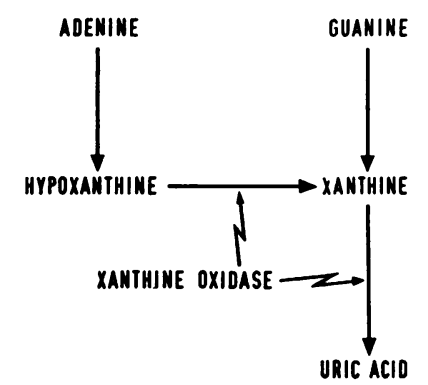

(b)

(b). - Site of action of xanthine oxidase. 


\section{Results}

The clinical course of the four patients is set out in detail below.

Case 1, an engineer aged 62 years, had a paternal uncle who had suffered from gout and his own gout had started at the age of 14. Acute attacks occurred about twice a year thereafter, although he found that he could often abort them by drinking large quantities of water. From 1952 onwards numerous tophi appeared on the hands, feet, knees, elbows, and ears.

Examination.-On his first admission to hospital in 1962 the serum uric acid was found to lie between $7 \cdot 7$ and $12.5 \mathrm{mg} . / 100 \mathrm{ml}$. Impairment of renal function was indicated by a blood urea of $116 \mathrm{mg} . / 100 \mathrm{ml}$. but there was no proteinuria. He was treated with probenecid (Benemid) $1 \mathrm{~g}$. daily. The tophi became smaller and stopped discharging; there were no further attacks of acute gout.

He was re-admitted in December, 1963, with severe oedema of the legs. The blood pressure was 120/70 and the jugular venous pressure slightly raised at $2 \mathrm{~cm}$. The heart was considerably enlarged; no murmurs were heard but there were numerous ectopic beats and the electrocardiogram showed changes consistent with mild ischaemia. Investigations showed a serum uric acid of $9 \cdot 2 \mathrm{mg}$. $/ 100 \mathrm{ml}$.; blood urea $76 \mathrm{mg}$./100 ml.; proteinuria $24 \mathrm{~g}$. in 24 hours; serum albumin/1.6 g./100 ml.; serum cholesterol $490 \mathrm{mg} . / 100 \mathrm{ml}$; 价moglobin $12 \cdot 2 \mathrm{~g}$.; white blood cells 4,000 .

The reason for the nephrotic syndrome was not evident and a renal biopsy (Dr. E. K. M. Smith) showed only a few foci of tubular destruction and fibrosis. Urates could not have been demonstrated in the tissue because of formol fixation, but no crystal spaces were seen. Possible causes considered included the probenecid which he had been taking for a year, and which has been reported to cause the nephrotic syndrome (Ferris, Morgan, and Levitin, 1961).

Treatment.-For this reason, and because probenecid in daily doses of $1 \mathrm{~g}$. and $2 \mathrm{~g}$. was producing only a moderate fall in serum uric acid (see Fig. $2 a$, opposite), it was decided to use HPP. Probenecid was stopped and while the serum uric acid was rising an acute attack of gout occurred in his right knee.

HPP was first given in a dosage of $100 \mathrm{mg}$. three times daily by mouth. This produced a slow fall in serum uric acid from 12 to $10 \cdot 1 \mathrm{mg} . / 100 \mathrm{ml}$. in 6 days. The dose was then doubled and the serum uric acid fell more rapidly, the lowest level being $5.7 \mathrm{mg} . / 100 \mathrm{ml}$.

To prevent further acute gout (which has been reported following the commencement of HPP treatment) the patient was also given colchicine $2 \mathrm{mg}$. daily, starting the day before HPP was commenced. On the 12th day of HPP treatment there was diarrhoea and oliguria, the blood urea rising from 90 to $130 \mathrm{mg}$. $/ 100 \mathrm{ml}$. Colchicine and HPP were both stopped for 3 days, during which time the diarrhoea ceased, the urine output returned to normal and the blood urea fell to its previous level. The serum uric acid level did not rise when HPP was stopped, perhaps because impaired renal function was delaying the latter's excretion. When HPP was recommenced in a dose of $300 \mathrm{mg}$. daily, the serum uric acid level remained between 6 and $7 \mathrm{mg}$. per $100 \mathrm{ml}$. The urinary uric acid level fell during therapy and although the urinary oxypurines rose from $3 \mathrm{mg}$. to about $60 \mathrm{mg}$. daily, there was an overall fall in urinary purine excretion from a mean level of $460 \mathrm{mg}$. $/ 24 \mathrm{hrs}$ before treatment to 370 mg./24hrs while HPP was being given (Fig. $2 b$, opposite). The addition of probenecid $2 \mathrm{~g}$. daily for 3 days caused a temporary increase in the urinary uric acid but little change in the serum level.

During this admission the oedema disappeared almost completely, proteinuria fell to $2 \mathrm{~g}$. daily, serum albumin rose to $3 \cdot 3 \mathrm{~g} . / 100 \mathrm{ml}$. and serum cholesterol fell to 250 mg. $/ 100 \mathrm{ml}$. Reticulocyte counts, bone marrow, and serum alkaline phosphatase remained normal.

Progress.-The patient was discharged in February, 1964, when he was taking $300 \mathrm{mg}$. HPP daily; 2 weeks later the serum uric acid was $6.8 \mathrm{mg} . / 100 \mathrm{ml}$. with a urinary uric acid of $280 \mathrm{mg}$. $/ 24 \mathrm{hrs}$ and a urinary oxypurine level of $75 \mathrm{mg}$. $/ 24 \mathrm{hrs}$.

In April a mild, patchy, dry erythematous rash was observed over the face, arms, and upper thorax (the patient had not noticed it); 2 days later he developed a weeping eruption on the lower abdomen and the periumbilical skin became excoriated. The rash was thought to be due either to a drug reaction or possibly to seborrhoeic dermatitis. HPP was stopped and the rash faded following the use of local hydrocortisone and calamine cream; 6 weeks after the rash had developed HPP was recommenced in a dose of $300 \mathrm{mg}$. daily and no further untoward reactions have occurred during the 6 weeks which have since elapsed.

Comment.-A patient with tophaceous gout and renal impairment also had the nephrotic syndrome, possibly due to probenecid. HPP $600 \mathrm{mg}$. daily produced a satisfactory fall in serum uric acid, which was maintained with a dose of $300 \mathrm{mg}$. daily. HPP may, however, have been a causative factor in the skin eruption which developed several weeks after the drug was started.

Case 2, a housewife aged 72 years, had begun to suffer from gout in 1946 at the age of 54 . There was no family history of gout. She had numerous tophi and those on her right middle finger and left little toe were discharging and infected. She was having two acute attacks of gout every year. The only uricosuric therapy had been phenylbutazone for a short period in 1962.

Examination.-The blood pressure was $230 / 110$, the heart was enlarged, and the jugular venous pressure was slightly raised; there was no oedema and physical examination was otherwise normal. The electrocardiogram showed changes of ischaemic heart disease. Blood urea was $59 \mathrm{mg} . / 100 \mathrm{ml}$.; cholesterol $320 \mathrm{mg}$. $/ 100 \mathrm{ml}$.; proteinuria $6 \cdot 7 \mathrm{~g}$. in $24 \mathrm{hrs}$. 
Fig. 2 (a).-Case 1, effect of probenecid (Benemid) and HPP on serum uric acid.

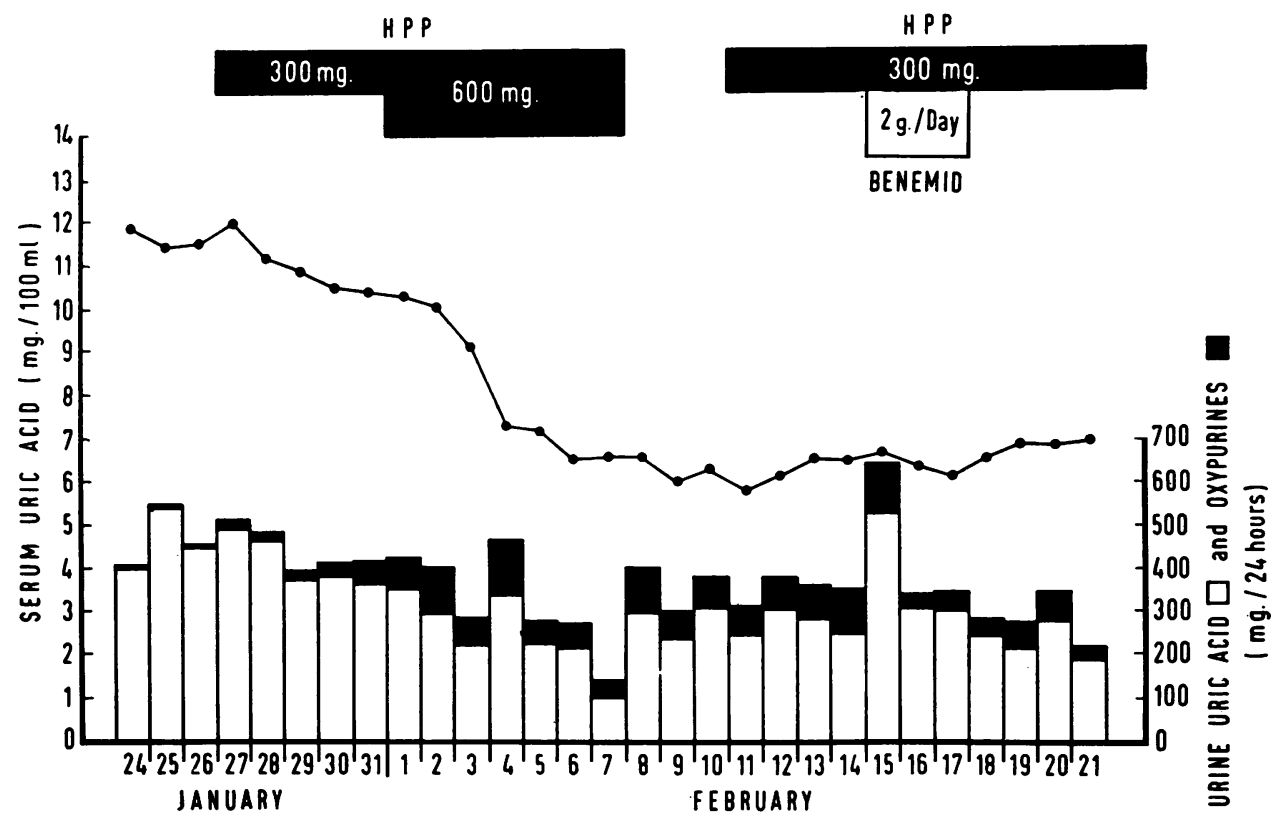

Fig. $2(b)$.-Case 1, effect of HPP on serum and urinary uric acid and on urinary oxypurines. 
Treatment.-HPP $300 \mathrm{mg}$. daily with colchicine $1 \mathrm{mg}$. daily was started in January, 1964. The serum uric acid level fell rapidly from $12 \cdot 2$ to $5 \cdot 7 \mathrm{mg} . / 100 \mathrm{ml}$. with a concomitant fall in urinary urate and a rise in urinary oxypurines. Again the rise in urinary oxypurines did not equal the fall in uric acid excretion (Fig. 3).

Probenecid $2 \mathrm{~g}$. daily was given for 4 days during HPP treatment; the urinary uric acid level rose but there was no significant increase in oxypurine excretion, and little change in serum uric acid level.

Progress.-After her return home in February, 1964, she remained well on $300 \mathrm{mg}$. HPP daily and the serum uric acid level (in a different laboratory) was later reported as $3.3 \mathrm{mg} . / 100 \mathrm{ml}$.

In May, 1964, her general practitioner found a mild petechial rash on the arms and back. The HPP was stopped and when she was next seen by us the skin was normal.

Comment.-In a post-menopausal woman with gout the serum uric acid fell satisfactorily on HPP $300 \mathrm{mg}$. daily, but a rash developed which may have been due to a mild drug reaction.

Case 3, a man aged 50 years, had first had gout in the left great toe in 1952 when he was 38 years old. A tophaceous olecranon bursa had been excised in 1961 after which he developed post-operative gout in the right foot and knee. The most recent acute attack had occurred in October, 1962, but for the 2 months before his present admission to hospital in March, 1964, he had had mild continuous pain in both feet.

Examination.-There was a small tophus on the right pinna but physical examination was otherwise normal.

The serum uric acid level on admission was 8.6 falling to $7.2 \mathrm{mg}$. $/ 100 \mathrm{ml}$. on a low purine diet. HPP $300 \mathrm{mg}$. daily then further reduced the serum uric acid to $4 \cdot 2$ mg./100 ml. (Fig. 4, opposite). Colchicine was not being given and 12 days after treatment began there was an acute attack of gout involving the tophus on his right ear which became red and tender, subsequently discharging tophaceous material. Seven days later an attack of gout occurred in the right ankle joint although he was by now taking colchicine $1 \mathrm{mg}$. daily as well as HPP, and the serum uric acid level had remained below $5 \mathrm{mg} . / 100 \mathrm{ml}$.

When the drug was discontinued there was a rapid rise in serum uric acid to $8.8 \mathrm{mg} . / 100 \mathrm{ml}$. with an accompanying rise in urinary uric acid. HPP $300 \mathrm{mg}$. daily was then started again and the serum uric acid level fell to $4.7 \mathrm{mg} . / 100 \mathrm{ml}$. While the patient remained on HPP the diet was changed to one of normal purine content, (i.e. just over $2 \mathrm{~g}$. daily), after which the serum uric acid level rose to $6 \cdot 2 \mathrm{mg} . / 100 \mathrm{ml}$.

Progress. - The patient was discharged taking HPP 300 mg. daily. There have been no further acute attacks of gout, but the chronic pain in his feet, of uncertain cause, has persisted.

Comment.-In a man with gout the serum uric acid fell rapidly during treatment with HPP $300 \mathrm{mg}$. daily,

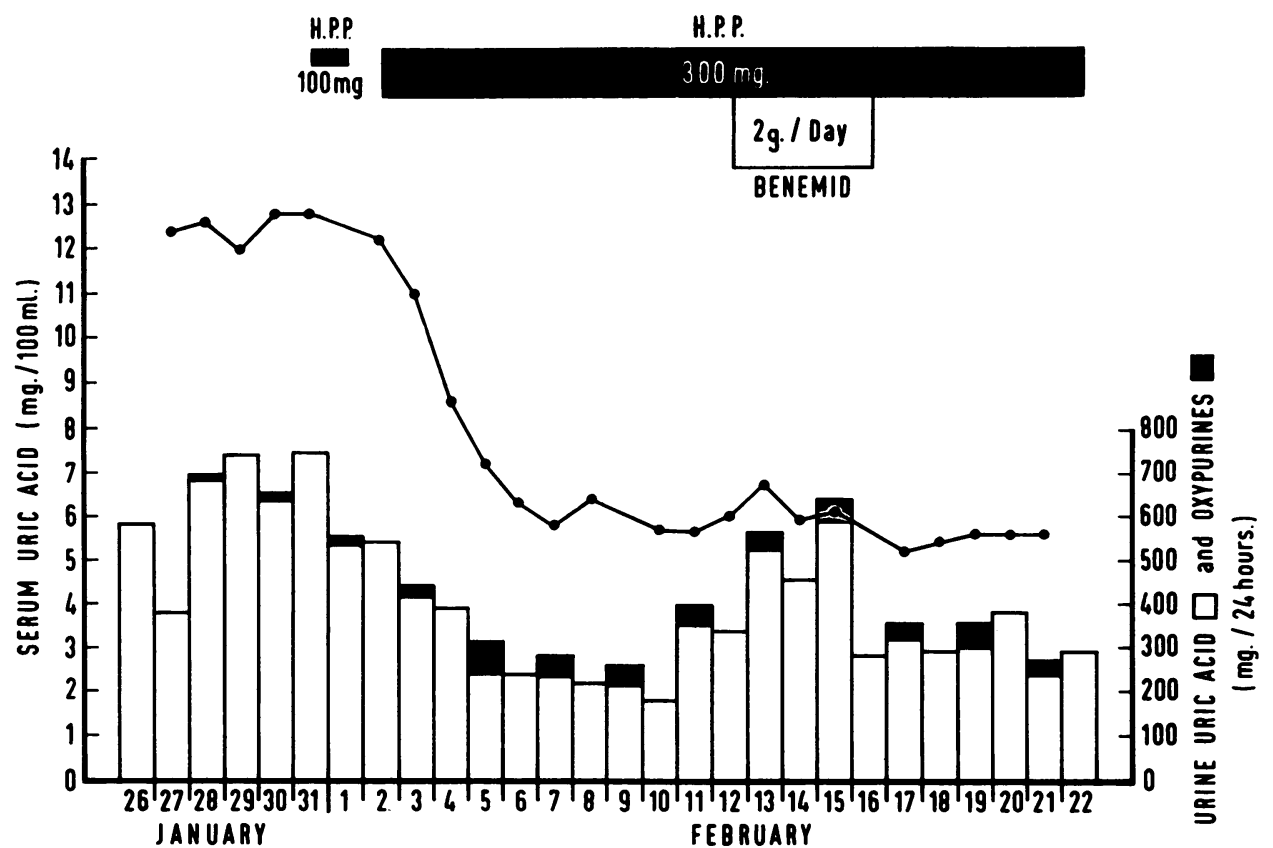

Fig. 3.-Case 2, effect of HPP on serum and urinary uric acid and on urinary oxypurines. Oxypurines estimated on alternate days only. 


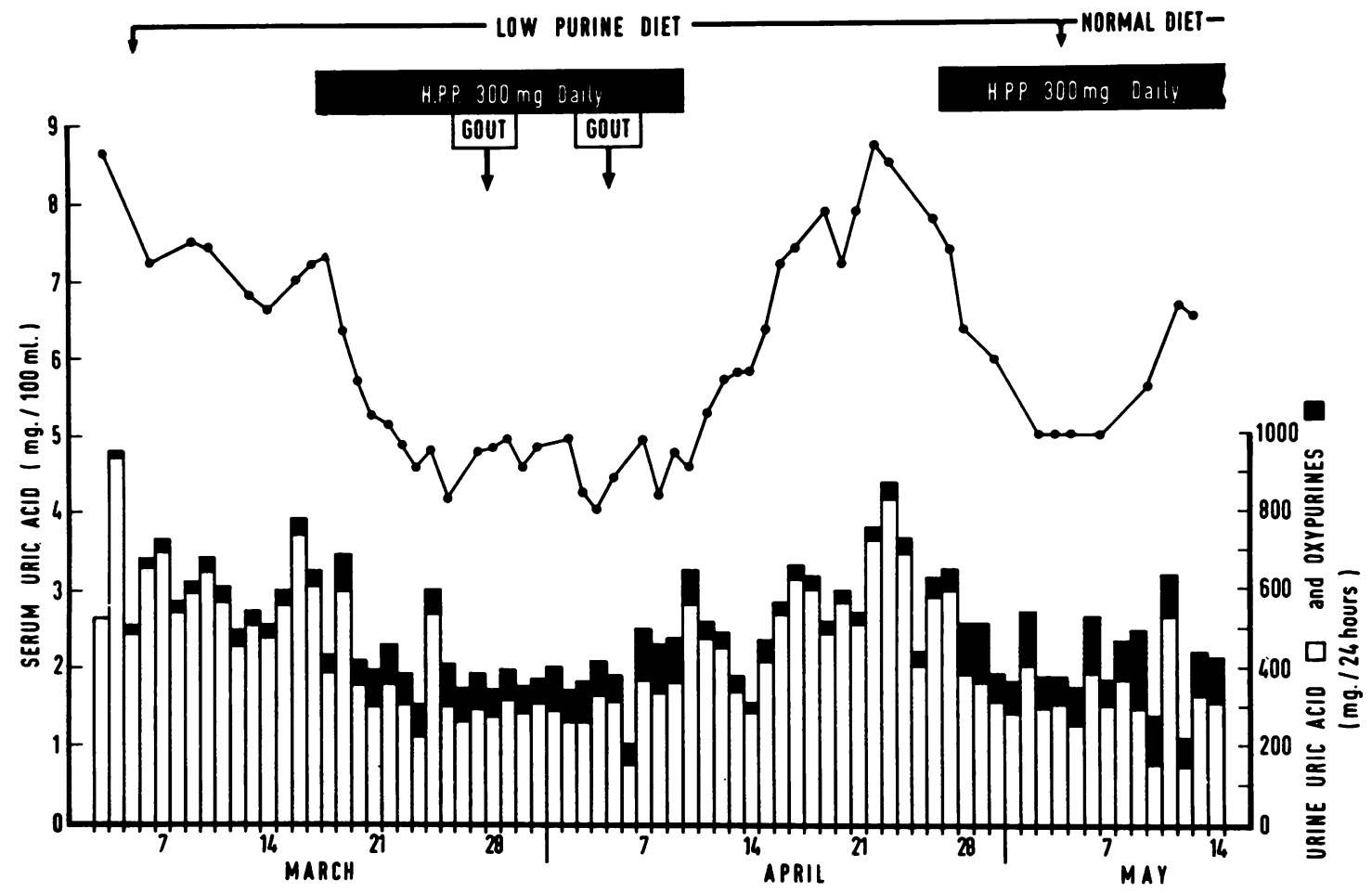

Fig. 4.-Case 3, effect of HPP on serum and urinary uric acid and on urinary oxypurines.

but he had two acute attacks of gout shortly after this therapy was started.

Case 4, a woman born in 1908, had calculi of unknown composition removed from the right ureter in 1946 when she was 38 years old. In 1949 the menopause was induced with radium because of menorrhagia (there had been thirteen pregnancies). In 1953 a staghorn calculus was removed from the left kidney. Gout started in 1959 in the left great toe. At various times she had been treated with probenecid, sulphinpyrazone (Anturan), and phenylbutazone, but all of them caused a rash. Recurrent urinary infections began in 1960. An excretion pyelogram in 1962 showed bilateral hydronephrosis and probably calcification in the lower pole of the left kidney. Two of her sons have gout and a sister (now dead) also had gout and renal calculi. Despite prophylactic colchicine the patient was having attacks of gout twice yearly.

Examination.-She was admitted to hospital in April, 1964, while recovering from a recent attack of gout in the right great toe. The blood pressure was 160/105. No tophi were observed. The serum uric acid level was $9.4 \mathrm{mg} . / 100 \mathrm{ml}$. and blood urea $56 \mathrm{mg} . / 100 \mathrm{ml}$. Because uricosuric drugs had previously caused a rash, HPP 300 mg. daily was given with colchicine $1 \mathrm{mg}$. daily, and the serum uric acid level fell from $9 \cdot 3$ to $5 \mathrm{mg}$. $/ 100 \mathrm{ml}$. (Fig. 5).

Progress.-Since her discharge she has felt very well apart from occasional aching in both big toes and the serum uric acid level has remained about $4.5 \mathrm{mg} . / 100 \mathrm{ml}$.

Comment.-A post-menopausal woman with gout, renal stones, and mild renal failure, had developed skin rashes with probenecid, phenylbutazone, and sulphinpyrazone, but she tolerated HPP $300 \mathrm{mg}$. daily with no side-effects, and the serum uric acid level fell satisfactorily.

\section{Discussion}

The results in these four patients confirm that HPP effectively lowers the levels of serum and urinary uric acid. As the oxidation of xanthine and hypoxanthine is suppressed their urinary levels rise, but in our experience, as in that of Rundles and others (1963) (but not in that of Klinenberg and others, 1963), this does not replace the fall in urinary uric acid, i.e. there is an overall fall in purine excretion. Significant tissue retention of oxypurines is unlikely, since Rundles and his colleagues found that the rise in serum concentration was slight (about 


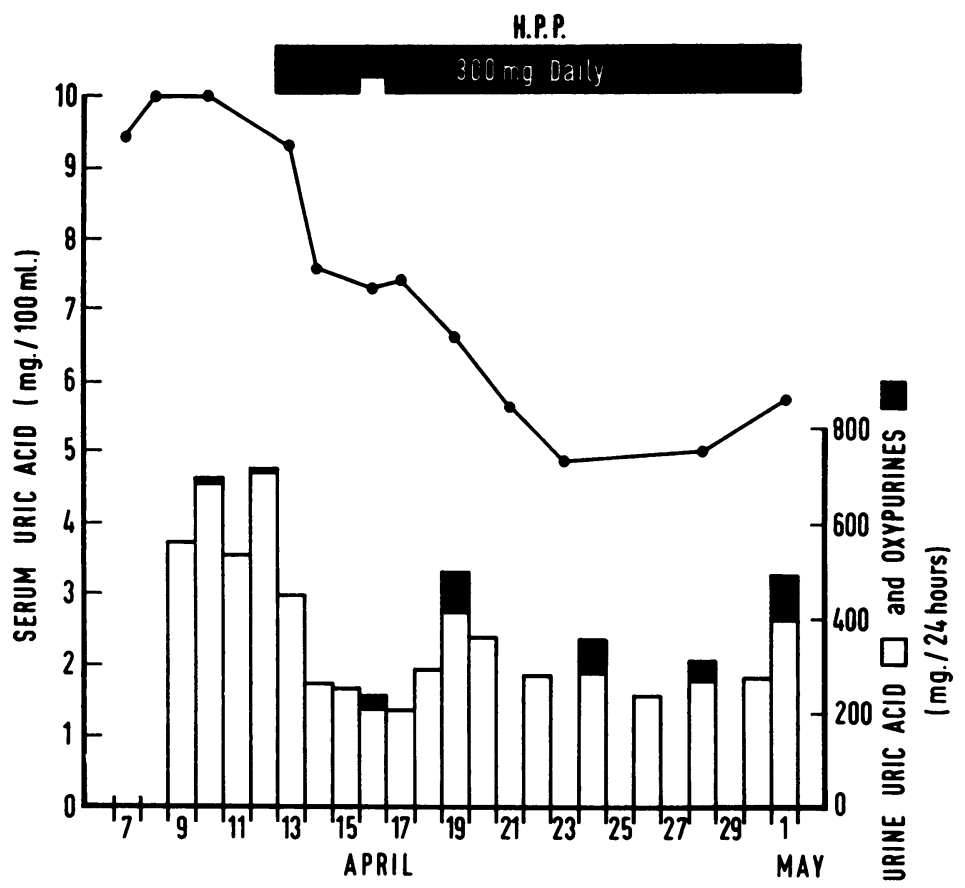

Fig. 5.-Case 4, effect of HPP on serum and urinary uric acid and on urinary oxypurines. Oxypurines estimated on 7 occasions only.

$0.15 \mathrm{mg}$. to $0.3 \mathrm{mg} . / 100 \mathrm{ml}$.). Other possibilities are that the oxypurines are re-utilized or that HPP also has an inhibiting effect on purine metabolism at an earlier stage.

No serious harmful effect of HPP has yet been encountered. In two of the four patients a skin eruption followed the commencement of treatment and, although it was not conclusively shown to be due to the drug in either case, this must be regarded as probable. Further experience, however, indicates that the incidence of this complication is not likely to be as high as these first figures suggest. Following the study of the four patients described here, a long-term therapeutic trial to compare the effects of HPP against those of probenecid has been started in patients who have not previously received uricosuric treatment; 3 months after starting the trial eleven patients are so far taking HPP and twelve probenecid; only one of the HPP patients has a mild rash, which developed the day after he began taking the tablets.

Case 3 had two attacks of acute gout shortly after starting treatment. In the comparative trial two of the patients taking HPP have also had acute gout, but so have two of the patients starting probenecid.
The development of gout may be related to the effect of a falling serum uric acid rather than to the particular drug used. In such a situation a tophus, previously more or less in equilibrium with the surrounding tissue fluid, starts to go into solution. Owing to fluctuations in tissue fluid concentration of uric acid there will be small foci of re-crystallization in the vicinity. Such deposition will then produce the inflammatory reaction of gout, perhaps by the mechanism of phagocytosis suggested by Seegmiller and Howell (1962).

It is too early yet to assess the place of HPP in the treatment of gout and hyperuricaemia. Only further observation will tell if such theoretical possibilities as xanthine renal stone formation (Klinenberg and others, 1963) or haemochromatosis (Ayvazian, 1964) will present themselves as practical difficulties. Nearly all patients with gout can be satisfactorily managed by various combinations of dietary measures, colchicine, and uricosuric drugs; but HPP seems at least to hold promise for patients in whom uricosuric drugs are ineffective or who cannot tolerate them (as in Case 4). Moreover, in patients whose kidneys are damaged by deposition of uric acid, it may be better to control hyperuricaemia by 
suppressing the formation of uric acid rather than by enhancing its renal excretion.

\section{Summary}

(1) From a study of four patients with gout it is confirmed that the xanthine oxidase inhibitor 4-hydroxypyrazolo (3,4-d) pyrimidine (HPP) effectively lowers the serum uric acid level. The urinary concentration of uric acid also falls and that of xanthine and hypoxanthine rises. There appears to be a slight fall in overall purine excretion. 300 mg. HPP daily has been shown to be an adequate maintenance dose in these patients.

(2) Two of the patients developed a rash during this therapy. This may have been due to the drug, but further experience indicates that the complication is not so common as these figures suggest.

(3) One patient experienced two acute attacks of gout during the first 3 weeks of therapy. It is believed that this was the result of lowering the serum uric acid rather than of the HPP itself. Concomitant colchicine treatment is therefore advisable when starting the drug.

We wish to express our thanks to the Department of Chemical Patholugy, Hammersmith Hospital, where estimations of serum and urine uric acid were performed, and to the Wellcome Foundation Ltd., who supplied the HPP.

\section{REFERENCES}

Ayvazian, J. H. (1964). New Engl.J. Med., 270, 18.

Ferris, T. F., Morgan, W. S., and Levitin, H. (1961). Ibid., 265, 381.

Folin, O., and Dennis, W. (1912-1913). J. biol. Chem., 13,469 .

Klinenberg, J. R., Goldfinger, S., Miller, J., and Seegmiller, J. E. (1963). Arthr. and Rheum., 6, 779 (abstract).

Popert, A. J., and Hewitt, J. V. (1962). Ann. rheum. Dis., 21, 154.

Rundles, R. W., Wyngaarden, J. B., Hitchings, G. H., Elion, G. B., and Silberman, H. B. (1963). Trans. Ass. Amer. Phycns, 76, 126

Seegmiller, J. E., and Howell, R. R. (1962). Arthr. and Rheum., 5, 616 .

\section{DISCUSSION}

Prof. E. G. L. Bywaters (Taplow): Although this is a very preliminary report we thought the Society would like to hear about it. I think there will be a big future for drugs of this type, especially in patients with renal disease or who cannot tolerate the usual uricosuric drugs.
DR. J. GLYN (London): Could Dr. Hall tell us if this drug is expensive?

Dr. Hall: We do not yet know, as it is not commercially available.

Prof. B. LACEy (Westminster): Is it likely that this is the best drug - the least toxic and so on-for inhibiting xanthine oxidase?

DR. Scort: I think that a large number of xanthine oxidase inhibitors were tested during the original search for something to prevent the degradation of 6-M-P, and HPP was found to be the most satisfactory from the point of view of both efficacy and toxicity.

Prof. E. G. L. Bywaters (Taplow): One of the most interesting points is the decrease of total purine excretion. This is quite unexplained and may mean there are possibly some snags to come.

Dr. Scort: These acute attacks of gout are interesting. As you see, one patient had two severe attacks. This sometimes follows the start of treatment with uricosuric drugs and Rundles also found a high incidence with HPP. This fits in with the Seegmiller hypothesis of the nature of the acute gouty attacks which postulates that phagocytosis of urate crystals is an essential part of the cycle. The serum uric acid is rapidly lowered and around the gouty tophus uric acid goes into solution; but because the level of serum uric acid is bound to fluctuate there are little foci of re-crystallization. These crystals and their phagocytosis may be the reason for the gout.

DR. W. R. M. AleXander (Edinburgh): We had a case becoming resistant to Probenecid and to Anturan and we managed to get a little of this material. Even with $3 \mathrm{mg}$. colchicine daily in addition, the patient developed quite an acute attack of gout, controlled with large doses of ACTH.

Prof. E. G. L. Bywaters (Taplow): It is important to remember that this is not a treatment for gout but for a uric acid retaining state. All patients on uricosuric drugs should be warned that attacks of gout may occur.

\section{Hydroxypyrazolopyrimidine (HPP) dans le traitement de la goutte. Observations préliminaires}

\section{RÉSUMÉ}

(1) L'étude de quatre malades atteints de goutte confirme que l'inhibiteur de l'oxydase xanthine, 4-hydroxypyrazole $(3,4-d)$ pyrimidine (HPP) fait baisser effectivement le taux sérique d'acide urique. De même, la concentration urinaire d'acide urique diminue, tandis que celle de xanthine et d'hypoxanthine augmente. L'excrétion totale de purine semble diminuer un peu. Une dose d'entretien de $300 \mathrm{mg}$. d'HPP par jour s'est montrée suffisante chez ces malades.

(2) Deux malades ont développé un exanthème pendant cette thérapie. Ceci pourrait bien être attribué au médicament, bien que d'autres expériences indiquent que cette complication soit moins fréquente que ces chiffres suggèrent. 
(3) Un malade a eu deux attaques aigus de goutte pendant les trois premières semaines du traitement. On pense que la baisse uricémique et non pas l'HPP en aurait été la cause. On conseille donc un traitement simultané par la colchicine au commencement de la thérapie par l'HPP.

\section{Hidroxipirazolopirimidina (HPP) en el tratamiento de la gota. Observaciones preliminares}

\section{SUMARIO}

(1) El estudio de cuatro enfermos con gota confirma que el inhibidor de la oxidasa xantina, 4-hidroxipirazole (3,4-d) pirimidina (HPP) hace bajar efectivamente la concentración sérica de ácido úrico. Baja también la concentración urinaria de este ácido mientras que sube la de xantina y de hipoxantina. La excreción total de purina parece algo disminuida. Una dosis diaria de mantenimiento de $300 \mathrm{mg}$. de HPP se mostró suficiente en estos enfermos.

(2) Dos de los enfermos desarrollaron un exantema durante este tratamiento. Esto se debe posiblemente al medicamento, pero experiencias ulteriores indican que esta complicación no es tan frecuente.

(3) Un enfermo sufrió dos ataques agudos de gota durante las tres primeras semanas de la terapia. Se cree que esto no fué el resultado de la HPP sino de la baja del ácido úrico en el suero. Se aconseja pués un tratamiento concomitante con colchicina al empezar la HPP. 